\title{
THE POLICE AND THE HUNGER MARCHERS
}

The use of informers and agents provocateurs by both the government and the police has not been uncommon in British history. Edward Thompson has made lengthy references to the employment of spies by the authorities in the period from 1790 to 1830. The highest levels of the London Corresponding Society were penetrated in 1794 by an informer known as "Citizen Groves", and, following this, use was made of informers in combating the Luddite movement, and in the Pentridge Rising, the Despard and Spa Fields Affairs, and, most important of all, the Cato Street Conspiracy of 1820.1 The use of political spies is also known to have occurred during the First World War and immediately afterwards, ${ }^{2}$ and allegations were made in Parliament in this respect during the period of the General Strike in $1926 .{ }^{3}$ The recent opening of the files of the Metropolitan Police for the 1930's has revealed that informers were also used during the unemployed disturbances of these years, in particular in the attempt to prevent the outbreak of violence during the marches on London organised by the National Unemployed Workers' Movement (NUWM) in 1932, 1934 and 1936, and on the occasion of the National Joint Council of Labour demonstration in Hyde Park in February 1933, although in these instances it has not been possible to establish the identity of the person or persons concerned.

The NUWM was formed in April 1921 to campaign for the provision of work for the unemployed by the State, with the alternative of "full maintenance". From the start, the organisation was led at both national and district level by unemployed skilled engineers, many of whom had been shop stewards during the First World War. The principal figure

1 E. P. Thompson, Making of the English Working Class (1963), especially pp. $82,135,485-94,604,616,663$. Thompson concludes that the use of spies is "an ancient part of British statecraft as well as of police practice".

2 See, for example, F. W. Chandler, Political Spies and Provocative Agents (Sheffield, 2nd ed., 1936).

3 Hansard, 5th Ser., CXCV. 
in its inception, and leader of the movement throughout its existence, was Wal Hannington, himself an engineer and former shop steward, who was National Organiser. Tom Mann was the movement's Treasurer in later years. The organisation was strongest in the great engineering centres, notably Glasgow, Coventry and Birmingham, and SouthEast Lancashire, ${ }^{1}$ though South Wales, where out-of-work miners provided the leadership, was an important exception in this respect. The NUWM was closely connected with the Communist Party of Great Britain, although unlike the National Minority Movement and other communist "satellite" organisations, it was always able to retain a fair degree of day-to-day autonomy. Hannington, who regarded the NUWM somewhat as his own "child", was particularly insistent about remaining independent of the Communist Party, and was able to use his influence to ensure that resolutions were occasionally passed by the movement's national conference reaffirming this independence. ${ }^{2}$ However, almost all the national leaders, and most of the local officials, too, were individual members of the Communist Party. Yet it is important to realise that the rank-and-file membership of the NUWM still looked to the Labour Party for political guidance. Although the national leaders may have thought in terms of a militant, revolutionary movement, the local unemployed member was far more concerned with the prospect of higher unemployment benefits, the abolition of the Means Test (introduced by the National Government following the financial crisis of August 1931), or the chance of new employment, whether on public works or as a result of a revival of trade following government measures. Because of this, the activities of the local branches were of a routine, almost mundane rather than revolutionary, nature, and consisted of frequent deputations to local authorities to press for the adoption of more relief schemes, or permission to represent the unemployed before Courts of Referees and later Public Assistance Committees. This latter aspect was, in fact, the

1 This article is based on "The Responses to Unemployment in the 1930's, with special reference to South-East Lancashire" (Ph.D. thesis, University of Hull, 1970).

2 In April 1923, for example, the Third National Conference rejected a resolution calling for a united front with the communists. The Ninth National Conference at Derby in 1934 repudiated any suggestion that the movement was an "ancilliary" or "auxilliary" of the CPGB. There was, however, some truth in the argument used by leaders of the "official" Labour movement at the time, namely that the unemployed movement was deliberately hiding its association with the Communist Party in order to win Labour and Trade Union support. L. J. MacFarlane, The British Communist Party (1966), p. 126; Report of the Ninth National Conference of the N.U.W.M., 1934. For the National Minority Movement, see R. Martin, Communism and the British Trade Unions, 1924-1933: A study of the National Minority Movement (Oxford, 1969). 
most important work of the NUWM: few of their legal representatives had any training in such matters, but, after studying the insurance regulations, they became expert in arguing the technicalities of different cases and many claimants had their benefit restored or increased as a result.

The most active years for the unemployed movement were the early 1920's, and between 1929 and 1936, when unemployment in Great Britain was at its height. The first "national Hunger March" organised by the NUWM was held as early as 1922, when contingents of unemployed from Scotland, the North-East, Lancashire, the Midlands, South Wales and elsewhere, converged on London, arriving in the Capital in November. ${ }^{1}$ Between 1929 and 1936 five more national marches were held by the NUWM, each involving over a thousand marchers, with almost fifteen hundred men and women taking part on the 1934 and 1936 marches. $^{2}$ Each one ended with a major demonstration in Hyde Park, followed by a week of activity in London, involving further demonstrations, deputations to Ministers, the lobbying of MP's, and other similar events.

Throughout these years, relations between the unemployed movement and the police were always strained. Glasgow, Manchester, Merseyside, and especially London, were all, at various times, the scenes of veritable "battles" between unemployed demonstrators and the authorities: baton charges by the police were resisted by stonethrowing on the part of the unemployed. Over the years hundreds of arrests were made by the police, and, in 1932, two men died from bullet wounds in Belfast when police opened fire on demonstrators. ${ }^{3}$ The Metropolitan Police records for the 1930's throw further light on the subject of the police and the unemployed. Although much of the material contained therein is of a routine police nature, in parts the information is highly revealing. The indications are that at least one police agent reached the inner councils of the NUWM, and gained access to the most secret meetings of the movement's leaders. Although the information he was able to give to the police was not of the highest importance, the authorities were nonetheless able to make prior

1 T. Regan, The Hunger March of 1922: by one who was on it (Manchester, n.d.) 20 pp.; W. Hannington, The Insurgents in London (1923), 32 pp.; Never on Our Knees (1967), p. 112; Unemployed Struggles (1936), pp. 74 et seq. Also Home Office file HO 11275, Unemployed Marchers, November 1922 and February 1923.

2 Other hunger marches were held in 1929, 1930 and 1932; about two hundred men took part on the Jarrow March of 1936, the only march to receive the official support of the Labour Party Executive and General Council of the TUC. This march was organised by the Jarrow Town Council.

3 Times, 4, 12, 15 and 17 October 1932. 
arrangements for the policing of a number of important demonstrations, and, on several occasions, to thwart the unemployed leaders' most carefully laid plans. At the same time, there is no evidence to suggest that any of the officials of the NUWM were aware that information was being given to the police in this way.

Of fifteen files relating to unemployed disturbances in the 1930 's, nine are wholly concerned with the activities of the National Unemployed Workers' Movement, and five others directly or indirectly related. ${ }^{1}$ The earliest concerns a demonstration organised by the National Union of Ex-Servicemen, the precursor of the NUWM, which was held on the afternoon of 18 October $1920 .^{2}$ From the information contained in this file, an accurate picture of the events of that day can be compiled. ${ }^{3}$ Four other files concern the preparation and publication of a booklet entitled Meetings, Processions and Demonstrations: powers and duties of police, the first three parts of which were published in 1933, Parts IV and $\mathrm{V}$ appearing in 1934 and $1935 .{ }^{4}$ Although not entirely devoted to unemployed demonstrations, there is no doubt that the booklet was prepared with the NUWM in mind, since many of the powers and duties listed were those which had already been used, or which were later to be employed, in controlling meetings organised by the NUWM.

Several files contain evidence of police discrimination against the unemployed movement. On the occasion of the 1932 Hunger March, for example, a "very urgent and confidential" memorandum (dated 24 October 1932, three days before the marchers were due to arrive in

1 The remaining file concerned the May Day demonstration of 1933 (Metropolitan Police Records, Mepol 2, 3051). The police files were consulted at New Scotland Yard in the spring of 1970.

2 Mepol 2, 1958, Unemployed Processions, 1920-1925. Following the onset of the post-war depression in 1920, the first organisations of unemployed were local Ex-Servicemen's Organisations, whose sole purpose was to beg charity as a means of relieving distress. In October 1920, a conference of delegates representing the Ex-Servicemen's Organisations of eleven London boroughs was held, and the London District Council of unemployed was established, with Wal Hannington as Organiser. The NUWM followed from this.

3 Seven contingents of unemployed, who assembled at nineteen different points throughout the Capital, converged on Whitehall in support of a deputation of London Labour Mayors to No 10 Downing Street. See photographs in W.T. Rodgers and B. Donoughue, The People into Parliament: An Illustrated History of the Labour Party (1966), p. 87.

4 Mepol 2, 3033, Commissioners' directions about hostile demonstrations, July 1932; Mepol 2, 3035, "Meetings, Processions and Demonstrations", Pts I to III, November 1933; Mepol 2, 3037, "Meetings, Processions and Demonstrations", Pts IV and V, 1934-1935; Mepol 2, 3039, "Meetings, Processions and Demonstrations": Comments from police officials. 
London), was sent out from Scotland Yard to officers in charge of districts throughout Britain, urging that:

"To assist the Commissioner in taking any action he may consider necessary in connection with the Unemployed Demonstrations, will you please report as early as possible the names and addresses of any of the local or other leaders of the Communists or Unemployed against whom you possess evidence of incitement to create disturbance, or of participation in disturbances that have occurred."

This met with an immediate response. Details of twenty-three members of the Scottish and North-East contingents, their full names and addresses, police records and in some cases photographs, were sent to Scotland Yard within the next forty-eight hours. The Glamorgan Constabulary forwarded similar details of eighteen men, described as the "most prominent of the South Wales contingent". These included one man who was described as "a very dangerous agitator", who was "very defiant" when in contact with the police: "he refuses to acknowledge any kind of law and order, and has been convicted on several occasions for assaulting the police". At a major demonstration in Hyde Park on 27 October 1932, this man was one of fourteen persons arrested. He was fined $£ 5$ for obstruction, and was further described in the police records of the court case as "an agitator $[. .$.$] with a very bad$ reputation". 1

The main targets for the police, as in this case, were the unemployed leaders and other well-known militants, and the discrimination was, in part, directed against these men. There is no doubt that the leaders of the NUWM were kept under constant surveillance by the authorities during the Hunger Marches and at other times of widespread unemployed activity. One of the files kept on the 1932 Hunger March reveals that Wal Hannington, Harry Pollitt and Emrhys Llewellyn, Secretary of the NUWM, were all under observation. The Special Branch Daily Bulletin for 17 October 1932 recorded the movements of Hannington and Llewellyn for the previous day, and reported that Pollitt had been seen boarding a ship at Harwich bound for the Hook of Holland. ${ }^{2}$ During the 1936 March, the movements of Ronald Kidd, Secretary of the National Council for Civil Liberties, were closely watched. In a summary of the March, sent by the Police Commissioner to the Home Secretary after it had ended, Kidd was stated to have

1 Mepol 2, 3064, National Hunger March, 1932; Mepol 2, 3065, Hyde Park Demonstration, 27 October 1932. This man is known to be still alive, and his name has, therefore, been withheld.

2 Mepol 2, 3064, National Hunger March, 1932. 
been in Hyde Park during a demonstration on 8 November. The summary stated that Kidd was "well-known for his antipathy against the Police and their methods". Kidd was also reported as having been present in the Central Hall of the House of Commons on the afternoon of 10 November 1936, when several hundred marchers lobbied MP's. ${ }^{1}$ Almost all the Metropolitan Police tiles contain transcribed reports of speeches made by the unemployed leaders at meetings and demonstrations, and the two files relating to the 1936 March are no exception: particular attention here was paid to the Hyde Park demonstration on 8 November, at which the speakers included Hannington, Arthur Horner of the South Wales Miners' Federation, Aneurin Bevan, MP, and Clement Attlee, leader of the Parliamentary Labour Party. Detailed accounts of the speeches of all these men were sent to Scotland Yard. ${ }^{2}$

1 Mepol 2, 3053, Hyde Park Demonstration, 8 November 1936; Mepol 2, 3091, National Hunger March, 1936. In 1937, in an article in Civil Liberty, Kidd wrote: "It is disquieting to find that provocative agents have been employed within recent years for political purposes, to attempt to discredit political or economic movements which are disliked by the government of the day. The writer of this article and one of his friends witnessed two incidents of the use of agents provocateurs during the Hunger March of 1932. The discrediting of the Hunger Marchers was without doubt the deliberate policy of the Government in 1932 and 1934. In the latter year, the then Home Secretary, Sir John Gilmour, abused his public position by attempting to create a panic mentality before the arrival of the marchers. A day or two before they were due to arrive in London, Sir John, though the medium of the Press, warned the public not to be at large and to keep their children off the streets, and he advised shopkeepers to shutterup their windows." Kidd went on to describe an incident in a demonstration in London during the March, when two "roughly dressed" men, wearing scarves and cloth caps, in the midst of a police baton charge suddenly drew from under their coats regulation police truncheons, and proceeded to "lay about them", and made two arrests. At a moment when the demonstration appeared to be calming down, a "well-known" detective sergeant, dressed in a trilby hat, drew a missile from his pocket, and threw it at the mounted police. This action prompted a further baton charge. Civil Liberty, No 2, Autumn 1937; also, R. Kidd, British Liberty in Danger (1940), p. 145.

2 Mepol 2, 3053, Hyde Park Demonstration, 8 November 1936. The 1936 Hunger March attracted far greater support than any of its predecessors from the British Labour movement in general. Events in Germany since the coming to power of Hitler in 1933 had done much to bring about a new spirit of co-operation between the rank-and-file of the Labour movement and the left wing. A more sympathetic attitude towards the NUWM was one aspect of this change, and was first apparent on the 1934 Hunger March, when the unemployed movement was able to form an influential committee which publicly issued the call for the March. James Maxton, George Buchanan, Aneurin Bevan and Ellen Wilkinson were all members of this committee. In 1936, many local Labour parties, trades councils and trade union branches gave support to the March, and the South Wales Miners' Federation undertook responsibility for the South Wales con- 
Before considering the extent and importance of information supplied to the police by agents, it is worth noting at this point that a certain amount of correspondence between the NUWM and Scotland Yard was exchanged during the occasions of Hunger Marches, by which the police were kept informed of some of the plans of the unemployed leaders. In 1936, for example, Pat Devine, Secretary of the London Reception Committee of the NUWM, wrote to the Police Commissioner asking permission to hold a demonstration in Hyde Park. He also gave details of routes which would be followed by the various contingents on their way to the Park. In most cases permission was granted for the contingents to take the routes suggested by Devine; in some instances, however, where it was felt delays to traffic might occur, alternatives were proposed. ${ }^{1}$ Similarly, the file on the 1934 March contains a telegram from a London district Superintendent to Scotland Yard, which stated that:

"Information has been received from Mr. [Harry] McShane, leader of the Scottish contingents of hunger marchers, that on Friday, 2 March at 2.30 p.m., they will march to Woolwich, arriving at the Commonwealth Buildings, George-Street, at 5 p.m., where they will have tea, leaving at 5.45 p.m. They will then march to Plumstead Baths, where a meeting will be held which is expected to last for about one hour."2

There is no evidence to suggest that any of the information supplied to the police by the leaders of the NUWM in this way was in any respect false or intended to mislead the authorities.

Less reliable was that information given to the police by "casual" informers. In some instances, what was suggested with regard to the intentions of the unemployed was absurd, though the police pursued all items of information as a matter of course. ${ }^{3}$ During the 1932 March, for example, information was received by police that, in order to divert attention from a demonstration to the House of Commons, planned for 1 November, fifty man had been assigned the task of wrecking the statue of Eros in Piccadilly Circus shortly before the main demonstration was due to commence. At the same time, casual labourers from London Docks had been invited to attend the

tingent. Seven other Labour MP's besides Attlee and Bevan spoke at the Hyde Park demonstration on 8 November 1936.

1 Mepol 2, 3053, Hyde Park Demonstration, 8 November 1936.

2 Mepol 2, 3071, National Hunger March, 1934.

3 E. P. Thompson, writing of the early nineteenth century, suggests that, since the informer was paid by "piece-rate", "the more alarmist his information, the more lucrative his trade". E. P. Thompson, op. cit., p. 485. 
main demonstration, and had been asked to bring with them their hooks (used for handling bales of paper, etc.). In addition, an Inspector from Cannon Row Police Station informed Scotland Yard that:

“At 12.45 a.m., 26 October 1932, Mr. William Gilbert, 44, Hereward Road, Upper Tooting, H.C. [Hansom Cab] Driver, Badge No. 8166 , called at this station and stated that on the evening of 25 October, in the "Greyhound" Public House, Clapham Road, he had overheard a conversation between three men in which it was stated that it was the intention of the unemployed demonstrators to arm themselves with feathered darts for the purpose of throwing at the Police during the forthcoming demonstration on Thursday, 27 October 1932."1

This is the only occasion on which the name of the informer is to be found in the police records and it is clear that this man was acting in the public interest. There is no evidence, however, to suggest that what he alleged to have overheard was part of the intentions of the NUWM, nor is there evidence to support the charges concerning the London dockers or the attempt to wreck the statue of Eros. More plausible, perhaps, was a memorandum sent to Scotland Yard by a London district Police Station on 25 October 1932, which stated that information had been received which suggested that parties of "Communists" would enter restaurants during rush hours, order expensive meals, and at a given signal leave without paying. As before, there is no evidence to suggest that this ever formed part of the plans of the NUWM, but its originality is typical of a later campaign of the movement, which involved such exploits as blocking Oxford Circus with recumbent bodies, attaching a banner on which was written "For a Happy New Year the unemployed must not starve in 1939" to the top of the Monument on Tower Hill, and the holding of a mock funeral procession through the streets of London, bearing a black coffin on which had been painted in white letters "He did not get winter relief". The memorandum stated that this information had been disclosed by a seaman from the East End of London, but his name was not given, nor was any indication made as to how he had obtained this information. ${ }^{2}$

In six of the files examined, Special Branch reports were found, several beginning with the statement "The following information has been received" (in some cases "The following information has been received from a reliable source"). These reports are quite numerous,

1 Mepol 2, 3064, National Hunger March 1932. It is not clear as to how the information relating to the statue of Eros and concerning the Dockers reached the police.

2 Ibid. 
and some are fairly lengthy. One of these files relates to a National Demonstration on Unemployment held in Hyde Park on 5 February 1933, and organised by the National Joint Council of Labour (a body composed of representatives of the General Council of the TUC and the National Executive of the Labour Party). The Communist Party and NUWM were both officially excluded from this demonstration, though both organisations announced that they intended to take part regardless. The Scotland Yard file on this demonstration, ${ }^{1}$ which includes the usual details of divisional arrangements to supervise the various contingents as they made their way to the Park, also contains transcriptions of interviews between senior Scotland Yard officials and the two chief marshals appointed for the demonstration by the National Joint Council. At one of these interviews, the two men explicitly stated that the NUWM had not been invited to take part.

Yet the file contains a précis of information, dated 4 February 1933, on the plans of the NUWM and CPGB with regard to the demonstration. This reported that both bodies were planning to take part in the demonstration, and that it was expected "that the leading members of these movements will endeavour to speak from the official T.U.C. platforms, or hold independent meetings". The Communists had "stated their intentions to turn it into a militant demonstration against the wishes of the T.U.C." An attempt was to be made "to take four rostrums into Hyde Park for the use of the N.U.W.M. and Communist Party officials, although permission has been given for only one platform". Furthermore, "Instructions have been given to Wal Hannington to endeavour to get on to one of the T.U.C. platforms and speak therefrom. A bodyguard of ten men, under the control of Henry Van Loo, has been selected to look after him." Finally, the précis stated that "Communist Seamen in the Seamen's Minority Movement are due to leave West Ham Recreation Ground at 11.15 a.m., Newby Place, Poplar, at 11.30 a.m., and join up at the Labour Hall, Stepney Green, with the T.U.C. demonstration", while members of the Busmen's Rank and File Movement "will assemble at Temple Pier, Embankment, at 1 p.m."

This précis was based largely on a Special Branch report, received by Scotland Yard on the previous day, which stated that:

"The following information has been received. The Organising Bureau of the N.U.W.M. met this morning (Friday) at 59, Cromer Street, W.C., to consider the official refusal of permission to speak from their own platform in Hyde Park on Sunday next (5 February). It was decided that despite this ban, four rostrums,

1 Mepol 2, 3050, National Joint Council Demonstration, 5 February 1933. 
the property of the C.P.G.B. Locals, would be taken into Hyde Park for the use of N.U.W.M. and C.P.G.B. officials. The opinion was expressed that one, if not more, of the rostrums could be safely erected and surrounded by sympathisers before the police would become aware of it. The police would then, it is considered probable, use their discretion and not take action.

Wal Hannington has been instructed by the Communist Party to endeavour to get on one of the T.U.C. platforms and speak therefrom. He does not appreciate his selection for this task as, having just come out of prison, he considers that someone else should, to use his own words, 'take a chance of being pinched'. However, as he is 'under a cloud', he is expected to make the attempt. A bodyguard of ten men, under the control of Henry Van Loo, of 30, Church Row, Limehouse, East, has been selected to look after Hannington.

The Communists consider that the trouble, if any, will break out on the Embankment. In order to get support, the N.U.W.M. and Communist Party members have been instructed to form up as units behind 'militant' (that is, sympathetic with Communism) Trades Union Branches. To deal with possible eventualities on the Embankment, Frederick Bayes Copeman (the ex-'Invergordon' naval rating), the London District Organiser of the N.U.W.M., will be assisted by Thompson, leader of the Southwark unemployed.

In various East End Branches, the rank-and-file have been told that should a T.U.C. marshal object to any bannerette carried in the N.U.W.M. ranks, and request the Police to eject the bearer or seize the bannerette, they should not concentrate on resisting Police, but on the T.U.C. official concerned."1

The same file contains a similar account relating to an earlier meeting of the Organising Bureau, also held at the Minority Movement offices, on Thursday, 26 January 1933. The report stated that about twenty persons had been present at this meeting, which began with three cheers for Wal Hannington, who had just been released from gaol. Hannington was reported to have made a lengthy statement concerning "his recent arrest and sentence, which he described as a

1 Ibid. 59 Cromer Street was the headquarters of the National Minority Movement. On 4 February, Scotland Yard informed the NUWM that they would, after all, be allowed to take one rostrum into the Park. There is no evidence to indicate that the NUWM tried to take more than one platform into the Park, or that Hannington tried to reach one of the TUC platforms. 
'frame-up' to get an excuse to search the offices of the N.U.W.M."1 There was also a third report of a meeting of the London District Council of the NUWM, again held at 59, Cromer Street, on the evening of 19 January. Those present had included Fred Copeman and Pat Devine, acting National Secretary of the NUWM in place of Emrhys Llewellyn. Discussion at this meeting had centred on the imprisonment of Tom Mann, ${ }^{2}$ and on the possibility of arranging a welcoming demonstration for Hannington on his release. Included with this report was a copy of a circular from Copeman, dated 14 January 1933, to all branches and district councils of the NUWM, urging that where provincial demonstrations were being planned in support of the National Joint Council demonstration, "We [that is, the NUWM] do everything possible to turn them into militant demonstrations against the wishes of the T.U.C." In addition, there was a copy of a circular from Copeman to all members of the National Administrative Council of the NUWM, also dated 14 January, reminding them that the next quarterly meeting of the Council was to be held in London on 19 January.

All this is obviously of considerable importance. There can be no doubt that a police agent was responsible for this information reaching the authorities, and it would seem possible that the same person was involved on all three occasions. There is nothing in the NUWM records to suggest that the unemployed leaders were aware that their plans had been betrayed in this manner; nor did Wal Hannington make mention of the fact in any of the books he wrote about the NUWM. ${ }^{3}$ Each of the

1 Hannington was sentenced to three months imprisonment in November 1932 on a charge of attempting to cause disaffection among the police. $\mathrm{He}$ was arrested at the NUWM offices on 1 November 1932.

2 Mann and Llewellyn were both gaoled for two months in December 1932 on charges of incitement and disturbing the peace. The Seditious Meetings Act of 1817 and an Act of 1360 were invoked to bring about the sentences, which the Magistrate himself admitted were largely preventive. Mann and Llewellyn were each required to find sureties of $£ 200$ and bind themselves to keep the peace for twelve months, the alternative (which they chose) being imprisonment. The TUC General Council sent a letter protesting against the sentences to the Prime Minister, Ramsay MacDonald, and George Lansbury raised the matter in the House of Commons, and visited Mann, who was in his seventies, in Brixton Prison. The Executive Report of the Labour Party for the following year expressed the opinion that the sentences were examples of the "vindictive treatment meted out to political opponents on account of their pronounced and extreme opinions". Report of the 32nd. Labour Party Conference, 1932, p. 21.

${ }^{3}$ See Unemployed Struggles; Never on Our Knees; also Ten Lean Years (1940). Most of the reports of the quarterly meetings of the National Administrative Council were made available to the author during his research, and copies of these are now contained in the University of Hull Library. Since the NUWM was 
three meetings referred to above was held at the Minority Movement headquarters; yet, as will be shown, information also reached the police following similar meetings at the NUWM offices and a number of other places besides. It seems possible, therefore, although this cannot be proved, that the same person was responsible for passing information on all these occasions, and that this person was one of the most highly trusted members of the NUWM, whose presence at meetings of the London District Council, the National Administrative Council, and other important committees, was taken for granted. This, indeed, seems to be the only way in which the informer could have obtained copies of letters and circulars which were also then handed to the police. It is interesting to note, too, that the instructions to Hannington to make an attempt on the TUC platforms on 5 February 1933, came from the Communist Party, and that Hannington himself "did not appreciate his selection for this task", as it meant exposing himself to the risk of further arrest. The informant was sufficiently conscious of the situation to think it probable that Hannington would, nevertheless, make the attempt, since he (of this the informer was also aware) was out of favour with the Communist Party at the time (hence the comment "under a cloud").

Prior to this, the police had been supplied with information from similar meetings of the NUWM during the Hunger March of the previous autumn. Four files were kept on this March by Scotland Yard, and one of the most notable features of these is the number of transcribed reports of speeches made by unemployed leaders, most of them submitted by police sergeants and constables from notes taken at open-air meetings. As in the file kept on the 1933 demonstration, however, a number of Special Branch reports are also contained in these records, again beginning "The following information has been received". These are accounts of meetings of the London District Council of the NUWM, of the London Reception Committee, and in one instance an International Labour Defence meeting.

The earliest of these is a four page report of a meeting convened for the purpose of forming the London Reception Committee, held at Friars Hall, Blackfriars Road, in South-East London, on Sunday, 25 September 1932. Those present included Wal Hannington, Emrhys Llewellyn, and Sid Elias, Chairman of the NUWM. A Committee of nineteen was formed, the main purpose of which was to arrange accommodation for the hunger marchers during their stay in London.

never in a strong financial position, it is unlikely that an outsider attended these meetings to act as secretary, which rules out this possibility as a source for police information. 
The first meeting of the new committee was held in the public dining room of the "Pindar of Wakefield" Public House, Grays Inn Road, London, on the evening of 29 September. A detailed report of the meeting, five pages in length, is to be found in the Scotland Yard records. The main speaker was stated to have been Wal Hannington, and a lengthy report of what he had said was included in the Special Branch report. The same file includes two Special Branch reports of meetings of the London District Council of the NUWM. The first of these was held at the offices of the National Minority Movement on 20 October 1932, and representatives of more than twenty branches of the unemployed movement were stated to have been present, as well as Sid Elias, and also Bob Lovell, of International Labour Defence. The second meeting was held at the NUWM offices, 35 Great Russell Street, on 29 October. The first report was six quarto pages in length, the second four pages. In addition, the proceedings of a meeting of International Labour Defence at Canning Town Hall (Small) on Sunday 9 October were reported to the police, as was a further meeting of the London Reception Committee held on 21 October 1932 at Great Russell Street. ${ }^{1}$

The Scotland Yard file on the 1934 Hunger March contains further evidence of the existence and activities of a police informer within the unemployed movement. The summary of events of the March sent by the Police Commissioner to the Home Secretary after it had ended opened with the following statement:

"On 26 August 1932, information was received that the National Unemployed Workers' Movement was endeavouring to obtain signatures to a National Petition against the Means Test, which it was proposed to present to Parliament. Arrangements were then commenced by the leaders of the movement to organise a march of unemployed men and women on London..."2

The date given here (26 August 1932) was exactly one month before the date of the meeting to form the London Reception Committee for the 1932 Hunger March (25 September 1932), and is the earliest date in the Scotland Yard files on which what might be termed "inside information" of this kind was received. Since the last date on the 1932 March on which information was received by Scotland Yard (29 October 1932) was less than three months before the first reports of the NUWM plans for the National Joint Council demonstration were received by the police (19 January 1933), it is possible that the in-

2 Mepol 2, 3071, National Hunger March, 1934. 
former was the same person for all of these occasions, although this cannot be proved.

Nevertheless, while one file was being kept on the 1932 Hunger March, another was opened on the question of a national petition to Parliament, which eventually became the file on the 1934 Hunger March. The next information in this context, however, does not appear to have been conveyed to the police until February 1934, when a report was made to Scotland Yard following a meeting of Branch officials of the NUWM held at Marx House, Clerkenwell Green, on 20 February of that year. Several leading officials of the NUWM were present, and the main topic under discussion was the question of accommodation for the marchers once they reached London. With the contingents due to arrive on the outskirts of London on 24 February, accommodation had still to be found for the majority of them, and this problem was giving rise to some concern among the leadership of the NUWM. The same file also contains a Special Branch report of a meeting of the East London March Committee, again held on 20 February, at 82 Culloden Street, Poplar. ${ }^{1}$ Those present on this occasion included delegates from the West Ham, East Ham, Poplar, Limehouse, Stepney and other branches of the NUWM, as well as a number of the national leaders. The report stated that a lengthy discussion had taken place regarding plans for accommodating a number of the marchers in West Ham, and it was decided to press the local council into providing shelter for ten days for one hundred and fifty men.

Once again, it is possible that the same informer supplied both of these reports: of the national leaders, Fred Copeman, London District Organiser, was stated to have been present at both meetings, and it must, therefore, have been possible for others to have attended both. Since this was the only meeting of the East London Committee of which a record is contained in the police files, it seems probable that it was the only meeting of this Committee from which information was sent to the police. This being so, it appears even more likely that the informer in question was one of the national leaders: the presence of members of the National Administrative Council at meetings of the East London Committee cannot have been usual, and would appear to have been a direct result of the meeting of Branch officials held earlier in the day, and the growing problem of finding accommodation for the marchers.

Yet other informers did exist. A Special Branch report dated 21 February 1934 stated that "A report has been received from another reliable agent who has been with the Scottish contingent." The report

1 It is not clear as to what this address was; it may have been the offices of one of the East London branches, or the home of a local leader. 
continued: "the leaders have complete control over their men, some of whom are in possession of sticks which are described as 'formidable weapons' [...] It has not yet been decided whether the men will carry their sticks when they march into London, or whether they will be collected, and put into a lorry and taken to a 'safe place'." On a different subject, the report stated that "In addition to the Headquarters of the N.U.W.M. being protected against an attack by Fascists, No. 16 King Street, the head offices of the C.P.G.B., has established a permanent guard." The report concluded:

"Regarding the question of sticks, the following information has been received from another source. Arrangements are being made by the Workers' International Relief for supplying the Hunger Marchers with tea and sandwiches in Hyde Park on Sunday, February 25th. Vans are being hired for the purpose. A suggestion has been made by the more irresponsible section that the vans should be used to convey the sticks or missiles to the park for distribution, because the police would seize them at the assembly points if carried by the marchers."1

All this information may have been compiled from as many as three different sources. In the first place, the earliest indication that some of the marchers were in possession of sticks was received from an agent with the Scottish contingent, but "another source" was responsible for informing the police that an attempt might be made to take the sticks in question into Hyde Park on 25 February in refreshment vans. The measures taken to guard the NUWM and the Communist Party offices against possible attack from Fascist elements was information of an entirely different nature and may well have been received from a third source. None of these need necessarily have been the same informer who was responsible for passing to the police reports of the meetings of the Branch officials or East London March Committee referred to above.

The continued existence of a police agent within the highest circles of the NUWM is apparent from an examination of one of the files kept by Scotland Yard relating to the 1936 Hunger March. As in the case of the

1 Mepol 2, 3071, National Hunger March, 1934. There is no evidence to show that any attempt was made to take sticks or missiles into Hyde Park, although on the occasion of the 1932 Hunger March, the police confiscated 154 ash-sticks, many with nails protruding from their heads, from a lorry accompanying the Lancashire contingent to the Hyde Park demonstration, and a van that had somehow gained access to the Park was found by police to have sixty sticks inside it, hidden under foodstuffs (Hansard, 5th Ser., CCLXIX). The two incidents must not be confused. 
1934 March, this file was begun after Scotland Yard had received the following information, in July 1936:

"The Communist Party and the N.U.W.M. have for the past few weeks been considering the prospect of being able to organise a successful 'hunger march' from various points of the country to London in October or November next, and have now decided that the intense opposition to the new Unemployment Regulations can be exploited to secure this aim.

Steps are, therefore, being taken to set up the preliminary machinery for this purpose. [...] Every effort is being made to keep in the background the 'Party' character of the march and to make it as much an 'all-in' protest demonstration as possible."1

Following this, early in September 1936, Scotland Yard was informed of the proceedings of a meeting of the National Administrative Council, held in London on the last weekend in August, and attended by delegates from Scotland, South Wales, Lancashire, Northumberland and elsewhere. The main topic for discussion at the meeting had been the proposed Hunger March. A detailed account of a speech made by Hannington at the meeting, in which he announced that arrangements had been made for seven contingents to take part, is contained in the police file on the March. These contingents were to be from Scotland (one from Glasgow and one from Edinburgh), the North-East Coast, Yorkshire, Lancashire, Nottingham and Derby, and South Wales; there was also to be a women's contingent. ${ }^{2}$ Once again, therefore, Scotland Yard were given an early warning of the plans of the unemployed leaders. The police were also given information regarding a meeting of the Headquarters Advisory Committee of the NUWM, held at the movement's offices, on 8 September 1936, and a meeting of the London District Council, at Marx House, a few days later. In both cases, arrangements for the Hunger March were discussed. A report was also made to the police of a meeting held on 14 September 1936 at Toynbee Hall for the purpose of forming a London Reception Committee, at which Hannington was the main speaker. ${ }^{3}$

The same file contains a Special Branch report, the date of which was 18 September 1935, in which it was stated that information had been received that a conference of leading members of the unemployed

1 Special Branch report dated 25 July 1936 (Mepol 2, 3091, National Hunger March, 1936). It is likely that a number of earlier reports of the possibility of a hunger march being arranged by the NUWM had been received by Scotland Yard, hence the expression "for the past few weeks".

2 A small contingent of women first took part on the 1930 Hunger March.

3 Mepol 2, 3091, National Hunger March, 1936. 
movement was to be held in London on 26 September. Those expected to attend included Arthur Horner, of the South Wales Miners' Federation; Ted Williams of Liverpool, the appointed leader of the Lancashire contingent; Harry McShane, leader of the East of Scotland marchers, whose address was given as 69 John Street, Glasgow; Len Youle of Sheffield, who was to lead the Yorkshire contingent; and Dai Ley, who was to lead the marchers from Nottingham and Derby. The report also gave the names of the leaders appointed for the other contingents: the West of Scotland marchers were to be led by Councillor John Heenan, a member of the ILP; Maud Brown, the NUWM's Women's Organiser, was to lead the women's contingent; Wal Hannington had been invited to lead the Northumberland marchers. D. L. Davies, Labour MP for Pontypridd had been appointed Treasurer of the South Wales contingent. In addition to all this, a copy of a list giving the proposed routes of the seven main contingents was attached to the Special Branch report, although no dates had yet been decided upon.

The first meeting of the London Reception Committee for the 1936 Hunger March was held on 21 September, and the proceedings of this meeting, too, were reported to Scotland Yard. A Special Branch report of 24 September stated that those present at the meeting had included Wal Hannington, Emrhys Llewellyn, and Pat Devine, along with eight others. A copy of a letter dated 20 September 1936 from Wal Hannington to all branches of the movement was attached to the Special Branch report. This included a document (also attached) giving the routes and final timetables of the various contingents. Scotland Yard, therefore, knew as soon as the NUWM branches did the complete itinerary of the 1936 Hunger March.

Following this, information on three further meetings of the London Reception Committee was also made known to the police. The first of these, held on 12 October 1936, was attended by Hannington, Pat Devine, together with several prominent members of the British Labour movement, including Dr Edith Summerskill. The speeches of the two NUWM officials at the meeting were reported in detail. A copy of a letter from Pat Devine, urging them to support the Hunger March, was attached to the Special Branch report. So, too, was a copy of another letter, dated 9 October, again addressed to all London trades councils and trade union branches, but this one appealing for donations to the marchers' fund. This was signed by Ellen Wilkinson, MP, John Jagger, MP, G. R. Strauss, MP, Aneurin Bevan, MP, S. O. Davies, MP, Councillor J. E. A. King, a member of the London County Council, Ted Hill, Jenny Lee, Tom Mann and Alex Gossip, all members of the London Reception Committee. Soon after this date, the London Trades Council, the London Labour Party and the Co-operative 
Party decided to give their official support to the March.

An account of a second meeting of the London Reception Committee, held on the afternoon of 17 October, was also given to the police. A Special Branch report referring to this meeting gave details of the speeches made by Wal Hannington, Pat Devine, and other NUWM leaders to the meeting, and stated that Aneurin Bevan, Edith Summerskill, Maud Brown, Tom Mann and Len Youle were among those present. Finally, a third meeting of the Committee, held at the National Trades Union Club, New Oxford Street, on the evening of 19 October 1936, was the subject of a further Special Branch report. Thirty-two persons were reported to have been present on this occasion, including once again Mann, Devine, Maud Brown and Edith Summerskill. A detailed account of the speech made by Pat Devine to the meeting was included in this report. ${ }^{1}$

Thus it is evident that, from the summer of 1932 onwards, a number of police agents were at work inside the National Unemployed Workers' Movement. Nothing more about the identity of these persons is known. Much of the information appears to have been given to the police by only one informer: in particular, this would appear to be true in the case of accounts of meetings of the National Administrative and London District Councils of the NUWM, and also the Reception Committees formed for the 1932 and 1936 Hunger Marches. It is by no means certain, however, that one person alone was involved on all these occasions, and, during the 1934 Hunger March, as has been indicated, it is likely that three or more agents passed information to the police. In all, the police received reports from the following eighteen meetings:

- 1932 Hunger March Reception Committee, meetings at:

Friars Hall, Blackfriars Road, S. E. London, "Pindar of Wakefield" Public House, 35 Great Russell Street (NUWM HQ), September 1932; September 1932; - London District Council, meetings at:

59 Cromer Street (Nat. Minority Movement HQ), October 1932; 35 Great Russell Street, October 1932.

- International Labour Defence, meeting at:

Canning Town Hall (Small),

October 1932.

- Organising Bureau of the NUWM, meetings at:

59 Cromer Street,

59 Cromer Street, January 1933;

- London District Council, meeting at:

59 Cromer Street,

February 1933.

February 1933.

1 Ibid. 
- NUWM Branch Officials, meeting at:

Marx House, Clerkenwell Green,

- East London March Committee, meeting at:

82 Culloden Street, Poplar,

- National Administrative Council, meeting at:

11a White Lion Street (NUWM HQ),

- Headquarters Advisory Committee, meeting at:

11a White Lion Street,

February 1934.

February 1934.

August 1936.

- 1936 Hunger March Reception Committee, meetings at:

Toynbee Hall (inaugural meeting),

(not stated)

(not stated)

(not stated)

National Trades Union Club,

September 1936;

September 1936;

October 1936;

October 1936;

October 1936.

In addition, in August 1932, Scotland Yard were informed that the NUWM was considering the possibility of collecting signatures for a petition to Parliament in protest against the Means Test, while in July 1936 the police were informed that the NUWM had decided to organise a further national March on London. Both these instances were the first indications Scotland Yard received of these plans, and files were opened which became the 1934 and 1936 Hunger March files respectively. In neither case, however, is it clear from examination of the police records as to the source of this information, but it would seem likely that both items came from the attendance of one or more agents at similar meetings to those listed here.

Certain questions remain to be asked about the Scotland Yard records. The numbers of the files are not, in most cases, consecutive, although these were apparently the only records kept relating to unemployed disturbances in the 1930's. This is not, in itself, of great importance, but neither are the records in chronological sequence. Why, for example, does file number 3040 (relating to the Hyde Park demonstration of September 1934) come before that of the National Joint Council demonstration of February 1933, the number of which is 3050 ? Likewise, why does 3051, which concerns a demonstration in 1933, come before files 3064-3067, all of which relate to the 1934 Hunger March, while the file on the 1936 March is numbered 3053? Were records kept of the 1929 or 1930 Marches? Why is file number 1958 entitled "Unemployed Processions, 1920-1925", when the material therein concerns only one demonstration, and that held in 1920 ? Were records kept of other demonstrations in London in the period 1921-1925? It would appear so. Have some records, therefore, been destroyed? If so, what was the nature of the material contained in them? Was other information similar to that described in this article 
received by Scotland Yard on other occasions? Finally, might the name, or names, or at least further clues to the identities of the agents have been revealed, perhaps on the first occasion on which they passed information to the police? Answers to these, and other questions will presumably remain unknown. Without such information, only an incomplete, though nonetheless interesting picture, can be pieced together. 